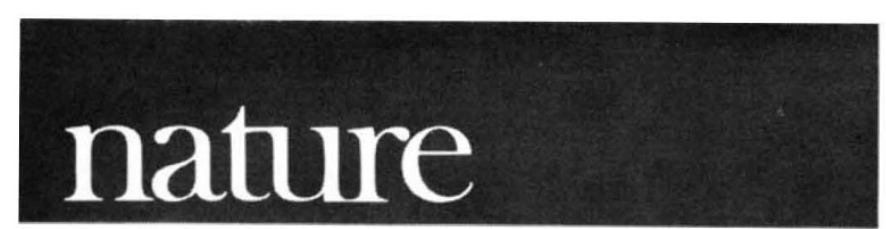

Volume 248

April 5, 1974

\section{Paying the Civil Service Scientist}

THE question of scientists' pay is not one for glib editorialising. Within the confines of a thousand words it is simply impossible to give a rational assessment of what should be done to the present simple pay structure for the enormously complex organisation that is the British Civil Service. What one can do is try and see broader issues. The contributions in Nature by Dr Leigh (248, 184; 1974) and Drs Gibson and Hawtin (in this issue) deserve careful reading because they clearly set out some of the fundamental questions underlying the present impasse.

In the late 1940s the Priestley Commission established that the pay of civil servants should be removed from the "cockpit of politics". To this end it proposed that parity be maintained with salaries outside the Civil Service and this, despite the inflexibilities of salary scales and increments, worked tolerably well for many years. Scientists were always in a potentially anomalous situation, since although they do not form a large percentage of all civil servants, they do account for more than half of Britain's scientific research manpower when scientists in fringe bodies (whose pay scales are coupled to civil service rates) are included. Far from avoiding pace-setting, which was Priestley's hope, scientific pay rates in the Civil Service cannot but set the pace for all scientists' pay. Up to 1971 the circularity inherent in this system was avoided by establishing broad parities between the scientific categories and their counterparts in the administrative, professional and technical grades. Since then the internal parities have been discarded and external parities sought through so-called 'pay research'. The result of this exercise did not satisfy the Institution of Professional Civil Servants, representing the scientists, and the matter is now with the Pay Board, whose decision is expected within weeks. There is no dispute, however, over the fact that scientists have slipped behind in internal parity during the dispute nor that they have conducted themselves with restraint. It is inconceivable that they should not be well rewarded by the Pay Board or that their forbearance should penalise them.

There are three salient points which need some emphasis: that going off an internal parity has created some nonsensical situations which deserve urgent attention; that the government, in deciding its own scientists' pay, is deciding the status of a profession; and that the role of government in science is worth continued questioning.

Every scientific civil servant can point to anomalies in structure. For instance scientists as they become more senior become more likely to administrate, and to main- tain a distinction between administrators who have followed different paths to their present position is manifestly absurd. Nor is the anomaly confined to the upper echelons, for many scientists could easily have been classed as technologists and vice versa, yet there are now hundreds of pounds between comparable categories.

More important than repairing these frayed edges, though, it is vital that the question of civil servants' pay is seen for much more than that. Like it or not, the Pay Board finds itself evaluating the financial rewards of all scientists and, because of this, affecting recruitment into science as whole and even the decisions that have to be made (as Drs Gibson and Hawtin point out) years before a young person starts work. Thus a decision consciously to differentiate between the pay that comparable arts and science graduates can command would have repercussions for many years to come. There is no visible sign that the government has decided that it wants a long term decline in numbers going into the scientific profession, indeed it has probably given little thought to the matter, but a settlement that leaves dissatisfaction in the scientific ranks will do much more than lead to temporary discontent.

Finally, and the greatest of the issues raised, does the government know what it wants of its own scientists?

It is obviously attractive to have all those scientific brains at one's disposal but are they always used to advantage? It would be unfair to ask for some sort of deal by which Civil Service science is reviewed in exchange for the coming pay award, but it does seem worthwhile to look again at the whole question of the government offering stable long term employment to such a large number of scientists. There is a feeling that the government holds too many scientists in an undemanding 'parking orbit' and industry and the universities should assume many of the piecemeal roles which the government has acquired. A fairly vigorous policy of hiving off over the next ten years, benevolently supervised by the government, may be no bad thing. And maybe to go with a reduced establishment, greater flexibility could go into pay negotiations. Collective bargaining removes much of the personal involvement that those with highly individual skill should have with their management. It would be good to see a greater devolution of negotiation on to management.

\section{0 years ago}

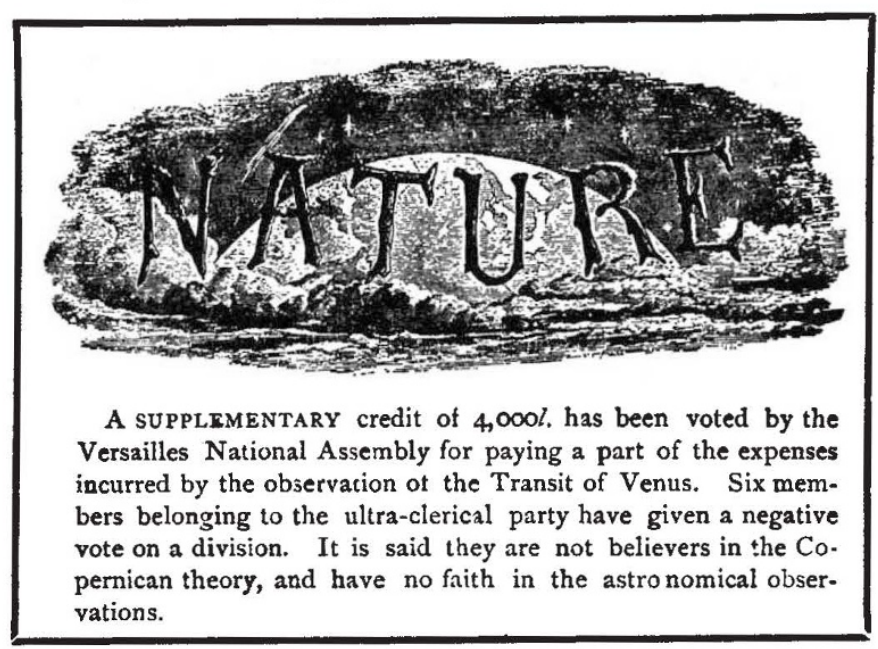

From Nature, 9, 452, April 9, 1874. 